ввівський н ціон льний університет імені в н вул. . орошенк, 41, м. ввів, 79000, кр їн

ведено результ ти польових т л бор торних досліджень структурно- грег тного ст ну сірих лісових грунтів смового обужжя. $\mathrm{x}$ р ктеризов но орг ніз цію структури грунту по профілю т ії зміни під різними біоценоз ми. ро н лізов но вплив нтропогенного чинник н пок зники структурного ст ну грунтів.

лючові слов : сірі лісові грунти, ясно-сірі лісові грунти, структур , грег т, морфологія, коефіцієнт структурності, коефіцієнт водостійкості.

чення про структуру грунту виникло з вдяки пр цям вид тних н уковців ХIX ст. юблєр , . іпновського, . ум хер , . ольні, . остичев т ін. озвиткові нового н пряму сприяли проблеми сільського господ рств й особливо боротьб з з сухою. сновники вчення неоднор зово н голошув ли н в жливості зернистості і шп рув тості структури в родючості т створенні сприятливих фізичних вл стивостей і водного режиму грунтів. пологетом в жливого зн чення грудкув тої структури грунтів був . ільямс, який зробив зн чний внесок у розвиток учення про структуру грунтів [3, с. 27].

оловні ет пи розвитку вчення про грунтову структуру в XX ст. пов'яз ні з імен ми . едройц , . околовського, . ояренко, . ул йков , . юлін , . чинського, . ідері, . оффе, . ершинін, . нтипов - p т єв, . нівця, . одлін, . евут , . р нцесон, . олгов, . уров, . н , . ічурін, . ек ревич , . ижов , . усс к, . узнецової, . оронін і б г тьох інших [3, с. 27].

труктур грунту приверт л ув гу н уковців з різних причин. ідом всебічність явищ структурності грунтів, зн чний вплив структури н вл стивості т процеси в грунт х, трудність експеримент льного вирішення деяких пит нь - ось ті обст вини, які виклик ли інтерес до вивчення структури з боку грунтозн вців - фізиків і хіміків, мікробіологів і мінер логів, теоретиків і пр ктиків сільського господ рств [3, с. 28].

ході вивчення структури грунту, перш $з$ все, необхідно розрізняти морфологогенетичне й грономічне розуміння цього поняття. морфологічному розумінні кожен грунт м є певну структуру, безструктурних грунтів нем, є грубопризм тичн чи стовпч ст структур може бути “доброю” чи “добре вир женою”. грономічного погляду, структурним грунтом н зив ють лише той, у якому перев ж ють грег ти розміром від 0,25 до 7 (10) мм, грег тів дрібніших (пил) бо більших нем бо ж їх не6 г то; усі інші грунти (як пилув ті, т к і глибисті чи м сивні) будуть у цьому розумінні безструктурними[3].

(C) енис ., 2012 
м термін “структур грунту” різні втори визн ч ють по-різному, тому він потребує уточнення і вдоскон лення.

труктурою н зив ють окремість ( грег ти), н які може розп д тися грунт. он скл д ється із поєдн них між собою мех нічних елементів (. урічев і . речін , 1969). лизьке до цього визн чення є в пр цях . ершинін (1959), . евут (1964) т ін. цьому р зі не роз'єднують поняття “структур ” й “грег т”, “структурн окремість”. визн ченням - евут , під грунтовою структурою (синоніми - грудочки, структурні окремості) розуміють утворення, які скл д ються з первинних мех нічних ч стинок (елементів) чи мікро грег тів розміром від 0,25 до 7 (10) мм (1969). ідповідно до цього н водять визн чення коефіцієнт структурності грунту [4].

грономічного погляду розрізняють спр вжні т непр вдиві грег ти (псевдо грег ти). стинні грег ти м ють велику шп рув тість і водотривкість; псевдо грег ти м лу шп рув тість, високу щільність і не стійкі до води бо, н вп ки, бсолютно водостійкі вн слідок цементув ння [4].

ід структурою тр диційно розуміють окремості різного розміру, н явні в грунті в різному поєдн нні. озрізняють морфологічне т грономічне розуміння структури. морфологічного погляду кожен грунт і його генетичний горизонт м $є$ певну структуру різної форми і розміру, з грономічного погляду, структурним є той грунт, у якому перев ж ють грег ти розміром 0,25-10,0 мм. г льноприйняте визн чення структури грунту н вів . чинський (1965): він пї розуміє як сукупність грег тів різного розміру, форми, шп рув тості, мех нічної міцності і водостійкості, х р ктерної як для кожного грунту, т к і для окремих його генетичних горизонтів. реб м ти н ув зі, що в генетичному грунтозн встві структур грунту - це розмір, форм $\mathrm{T}$ орг ніз ція твердих компонентів грунту і шп ринок між ними, тобто це вз ємне розт шув ння у грунтовому тілі структурних окремостей [2].

озміри структурних окремостей був ють досить різними як у різних грунт х, т к $\mathrm{i}$ в їхніх горизонт х. е стосується і форми грег тів. озподіл структурних грег тів у м сі грунту відповідно до їхніх розмірів н зив ють структурним скл дом грунту. ідповідно до розмірів (ефективних ді метрів) розрізняють мікро грег ти з розміром до 0,25 мм, мезо грег ти - 0,25-7 (10), м кро грег ти - пон д 7 (10) мм [2].

рунтові грег ти - це унік льний продукт грунтоутворення. грег т х відбув ються пр ктично всі грунтові мікропроцеси, х р ктерні для одного горизонту чи грунту 3 г лом. цьому р зі ст більне функціонув ння грунтових грег тів 3 безпечене: 1) сукупною дією генетичних горизонтів і формув нням у грунт х біохімічного, сорбційного, кислотно-основного й окисно-відновного б р'єрів. кл д і лок ліз ція їх у профілі визн чені конкретним типом грунтотворення; 2) функціон льними перебудов ми, які спрямов ні н підтрим ння ст більності структурних х р ктеристик грег ту (форм , розміри й енергія зв'язку між орг но-мінер льними грегов ними ч стин ми) [5, с. 450].

ослідженнями 3 кономірностей формув ння і розп ду м кро грег тів н водостійкі ч стини в широкому ді п зоні вологості - від гігроскопічної вологи до вологості к пілярного н сичення - з'ясов но, що розп д м кро грег тів н водостійкі ч стини підчиняється експоненці льному з кону. к тільки систем ст є триф зовою, сусідні ч стинки в м кро грег ті притиск ються з вдяки к пілярному тиску, і формуються міцні молекулярні зв'язки. рив розп ду м кро грег тів $є$ інтегр льною інформ тивною х р ктеристикою, як відобр ж є дин міку зміни міцності м кро грег тів [5, с. 450]. ісля пр ць . оз нов $(1975,1983)$ i, особливо, . оронін (1984) тр ктув ти структурність як зд тність грунту розп д тися н грег ти чи, н вП ки, зд тність фор- 
мув ти їх із мех нічних елементів і мікро грег тів, можн розгляд ти як н хронізм. вич йно, структур - це визн чений внутрішньогоризонтний рівень орг ніз ції грунтового тіл , який відобр ж є особливості грунтоутворення. ей рівень можн сх р ктеризув ти розміром, формою, щільністю будови структурних одиниць, зовнішніми і внутрішніми вл стивостями, і ще й специфічною дин мікою, як відобр ж є колив ння ф кторів грег ції і де грег ції, оскільки структур грунту протягом вегет ції з зн є к рдин льних змін. весні, будучи перезволоженим, і після декількох зимово-весняних циклів з мерз ння / відмерз ння, грунт м є мінім льну оструктуреність. отім процес грег ції інтенсифікується, і грунт може зберіг ти високий рівень оструктуреності ж до зими. к трив є з року в рік [3, с. 29].

ід ч с вивчення сірих лісових грунтів смового обужжя з стосов но порівняльногеогр фічний, морфолого-генетичний (профільний) порівняльно- н літичний методи. польовий період робіт з кл дено три мод льні ділянки.

од льн ділянк 1 розміщен н уликівському п смі н північний з хід від с. д нці м'янко- узького р-ну ьвівської обл. озрізи з кл дено в меж х пл топодібного, сл бкохвилястого підняття. рунтовий покрив предст влений ясно-сірими лісовими грунт ми. ділянці з кл дено дв розрізи: під лісом (розріз 1) і н ріллі (розріз 2).

од льн ділянк 2 розт шов н н лехівському п смі, н північ від с. орщовичі м'янко- узького р-ну ьвівської обл. ельєф - сл бкохвилясте, пл топодібне підняття. рунтовий покрив - сірі лісові грунти. кл дено дв розрізи: розріз 3 н ріллі, розріз 4 під лісом.

од льн ділянк 3 з кл ден н сл бкохвилястій вершині вододільного пл то мереківського п см , н північ від с. ори овківського р-ну ьвівської обл сті. рунтовий покрив - ясно-сірі лісові грунти. кл дено дв розрізи: розріз 5 н ріллі, розріз 6 під лісом.

ля вивчення морфологічних особливостей з стосовув ли профільний метод, що грунтується н обов'язковому вивченні грунту з поверхні й н всю глибину його товщі послідовно по генетичних горизонт х до м теринської породи. ін є х р ктерним тільки для грунтозн вств . ули відібр ні зр зки для л бор торно- н літичних досліджень і зр зки для структурно- грег тного н лізу.

етою дослідження є виявлення з кономірностей зміни структури сірих лісових грунтів по профілю т їх відмінностей між лісовими біоценоз ми й гроценоз ми. б’єкт дослідження - структурний ст н сірих лісових грунтів смового обужжя.

ивчення грунтової структури, як відомо, почин ється з визн чення іiї розміру і форми. і пок зники структури, як переконує досвід б г тьох дослідників, н дзвич йно інформ тивні. ем є ніяких сумнівів, що форм структурних окремостей грунту $\epsilon$ індик тором дії не тільки чинників структуротворення, і чинників грунтотворення з г лом. ожному типу грунту х р ктерний відповідний тип профільного розподілу структури, який визн ч ють 3 їі головною х р ктеристикою - формою грег тів. оведено, що зернист структур соціюється 3 кумулятивним процесом грунтотвореня, призмоподібн свідчить про ктивіз цію тонкодисперсної м си т ії мігр ції в грунті. якщо іноді в ре льному грунтовому профілі форм структурних окремостей не 3 вжди однозн чно збіг ється з перев жним грунтотворним процесом, то це тільки тому, що в цьому вип дку в грунті відбув ється відр зу декільк процесів, і тоді форм структури н був є зміш них рис [3, с. 81].

сно-сірі лісові грунти під лісом м ють грудкув то-зернисту структуру в гумусовоелюві льному, дрібногоріхув то-зернисту в елюві льному сл бкогумусов ному і горі- 
хув ту в ілюві льному сл бкоелювійов ному сл бкогумусов ному горизонт х (рис. 1). сірих лісових грунт х у лісовому біоценозі простежено в гумусово-елюві льному горизонті дрібногрудкув то-зернисту структуру, в ілюві льному сл бкогумусов ному грудкув то-дрібногоріхув ту і в ілюві льному сл бкоелювійов ному - горіхув то-призм тичну (рис. 2). тже є певні відмінності у структурній орг ніз ції між сірими т ясно-сірими лісовими грунт ми. цьому вип дку в сірих лісових грунт х у гумусовоелюві льному горизонті поряд з зернистою н явн дрібногрудкув т структур . Зн ки дрібногрудкув то-зернистої структури в ясно-сірих грунт х виявляються в елюві льносл бкогумусов ному горизонті, проте тут простежено озн ки пл стинч стості. ілюві льно-сл бкоелювійов ному горизонті ясно-сірих лісових грунтів структур $є$ горіхов тою, в сірому лісовому грунті в тому ж горизонті з'являється призм тичність $і$ структур є горіхув то-призм тичною. ясно-сірому грунті т к структур простежен глибше, в ілюві льному горизонті.

сно-сірі лісові грунти н ріллі в гумусово-елюві льному горизонті м ють грудкув тобрилув ту структуру, в ілюві льно-елюві льному сл бкогумусов ному - грудкув тогоріхув ту, в ілюві льному - горіхув то-призм тичну структуру (див. рис. 1). сірому лісовому грунті ріллі в гумусово-елюві льному горизонті перев ж є дрібногрудкув тобрилув т структур, в підорному - грудкув то-зернист, в ілюві льному сл бкогумусов ному - грудкув то-горіхув т (див. рис. 2). тже, в орному горизонті ясно-сірих лісових грунтів структур є грудкув то-брилув т, що зумовлено нтропогенним впливом н грунт під ч с його обробітку.

підст ві порівняння відмінностей у профільній орг ніз ції структури ясно-сірих і сірих лісових грунтів лісу і ріллі можн зробити висновок, що вн слідок господ рської діяльності відбулися зміни в морфології структури. кщо в грунт х під лісом у гумусовому горизонті структур зернист , то н ріллі - грудкув то-брилув т . ясно-сірому грунті під лісом униз по профілю структур із зернистої змінюється н дрібно грудкув то-зернисту і нижче по профілю н горіхув ту. ріллі структур грунту змінюється від грудкув то-брилув тої в гумусово-елюві льному горизонті до грудкув то-горіхув тої в ілюві льно-елюві льному і н горіхув то-призм тичну в ілюві льному сл бкоелювійов ному.

н логічною $є$ ситу ція в сірих лісових грунт х. прикл д структур в гумусовоелюві льному горизонті під лісом є дрібногрудкув то-зернистою, тоді як н ріллі дрібногрудкув то-брилув тою. одноч с уже в ілюві льному сл бкогумусов ному горизонті структур не змінюється іє грудкув то-горіхув тою. дн к н ріллі грунтовий профіль є витягнутішим і тут ілюві льний-сл бкогумусов ний горизонт розміщений н 10 см глибше. ріллі вн слідок господ рської діяльності у верхньому горизонті сірих лісових грунтів структур дрібногрудкув то-брилув т .

ількісним підтвердженням зміни структури по профілю є пок зник структурного ст ну (див. т блицю).

ясно-сірому лісовому грунті під лісом коефіцієнт структурності в гумосово-елюві льному горизонті змінюється від 0,18 до 0,67. ксим льне зн чення цього пок зник в середній ч стині гумусово-елюві льного горизонту, мінім льне - у його нижній ч стині. елюві льному горизонті коефіцієнт структурності ст новить 0,25 , в ілювільному - 0,31. сно-сірий лісовий грунт ріллі м є менший коефіцієнт структурності. ого мінім льне зн чення у нижній ч стині орного горизонту - 0,25 , м ксим льне в середній ч стині - 0,42, д лі в ілюві льно-елюві льному - 0,16-0,18, в ілюві льному сл бкоелювійов ному -0,16. 
ic

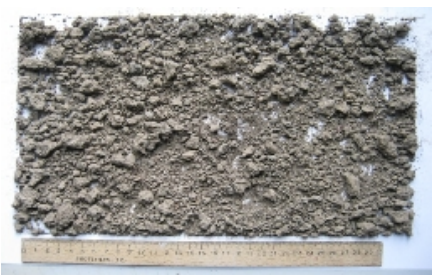

HE $2-10 \mathrm{~cm}$

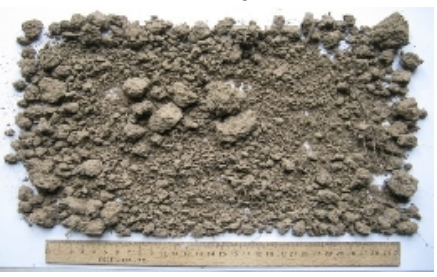

HE $10-20 \mathrm{~cm}$

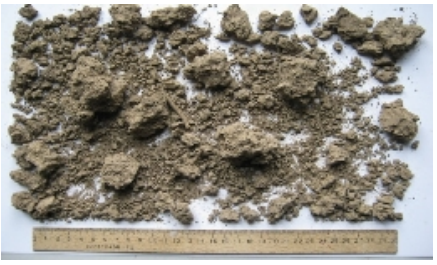

HE $20-29 \mathrm{~cm}$

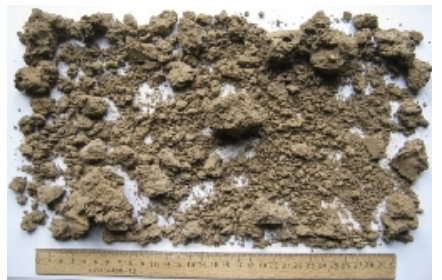

Eh $30-40 \mathrm{~cm}$

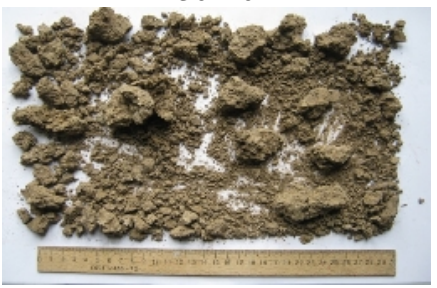

Eh $40-45 \mathrm{~cm}$

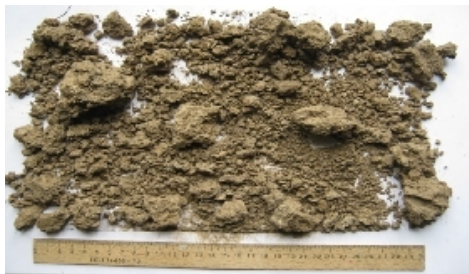

Ieh $47-57 \mathrm{~cm}$

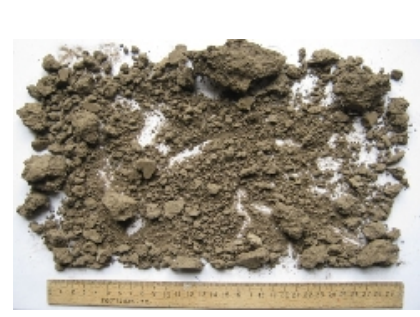

HEop 0-10 cM

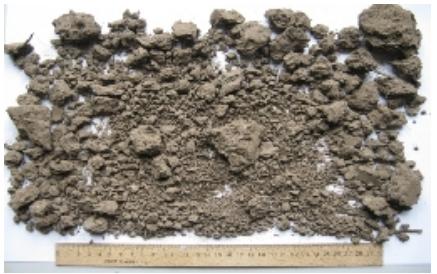

HEop 10-20 cm

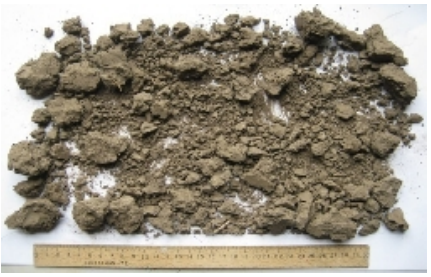

HEop 20-33 cM

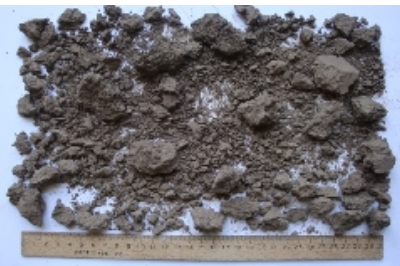

IEh $33-40 \mathrm{~cm}$

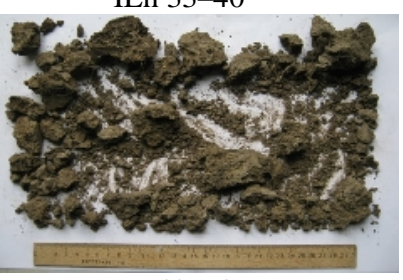

Ie $40-50 \mathrm{~cm}$

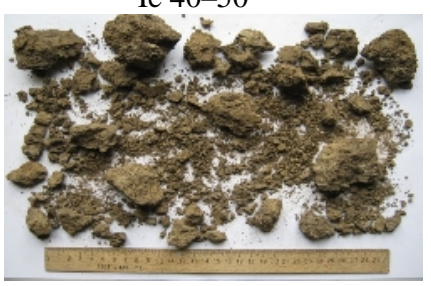

Ie $50-60 \mathrm{~cm}$

ис. 1. рофільний розподіл структури ясно-сірих лісових грунтів

смового обужжя. 
ic

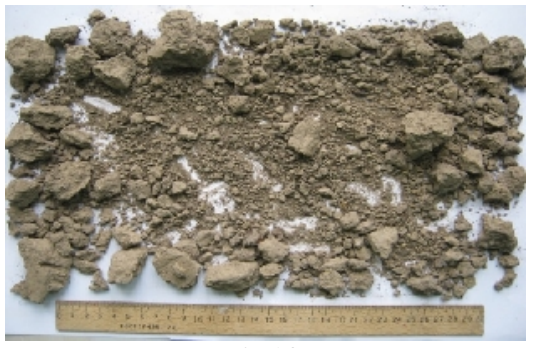

HE 2-10 cM

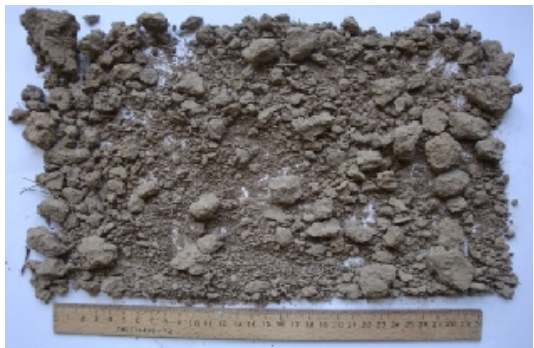

HE 10-20 cM

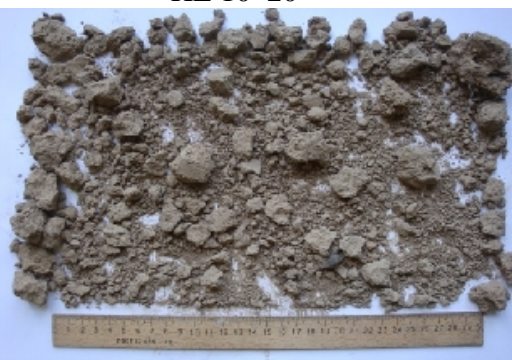

HE 20-26 cm

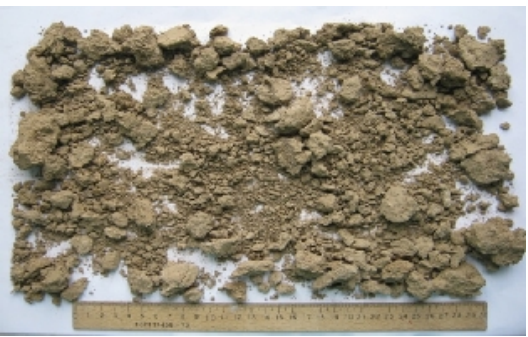

Ih $26-36 \mathrm{~cm}$

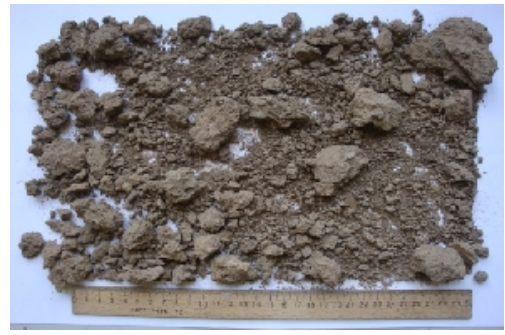

Ie $44-54 \mathrm{~cm}$

ис. 2. рофільний розподіл структури сірих лісових грунтів ілля

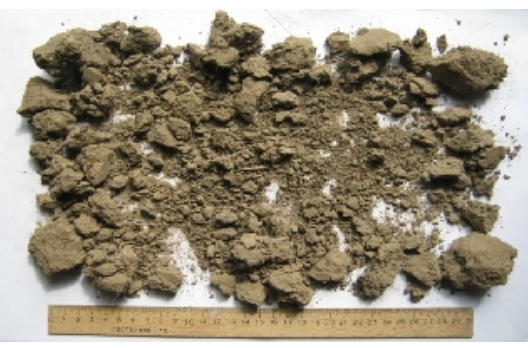

HEop 0-10 cM

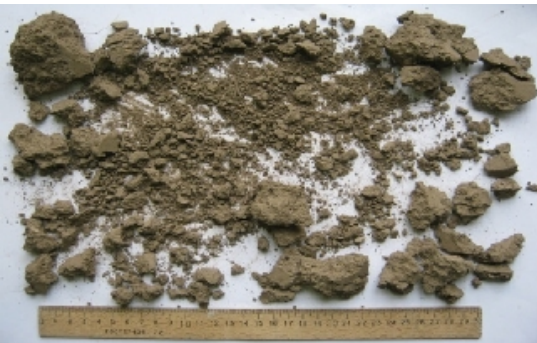

HEop 10-20 cм

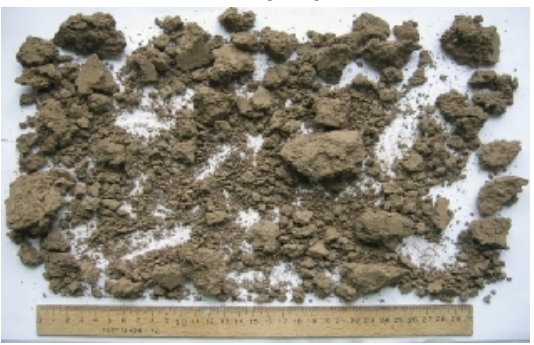

HEop 20-30 cм

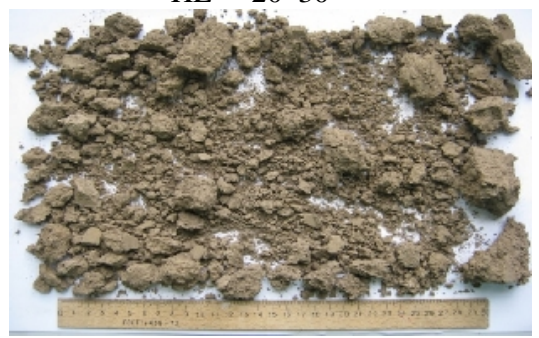

HEп/op 31-36 см

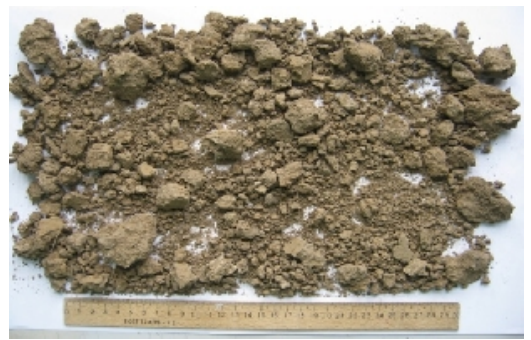

Ih $37-47 \mathrm{~cm}$

смового обужжя 
ля оцінки водостійкості структурних грег тів використ но коефіцієнт водостійкості з едведєвим (див. т блицю). прикл д, у ясно-сірих лісових грунт х коефіцієнт водостійкості у верхньому горизонті ст новить 0,64-0,74, під ріллею - 0,450,48. н чення цього коефіцієнт зменшуються вниз по профілю як під лісом, т к і під ріллею.

сірих лісових грунт х не виявлено великої різниці в коефіцієнт х структурності т водостійкості в грунт х лісу і ріллі. ід лісом коефіцієнт структурності в гумусовоелюві льному горизонті ст новить $0,30-0,43$, в ілюві льному - 0,4, коефіцієнт водостійкості в гумусово-елюві льному $0,60-0,71$, в ілюві льному - 0,50 (див. т блицю). ід ріллею коефіцієнт структурності у верхньому горизонті ст новить $0,14-0,27$, в підорному $-0,34$, в ілюві льному $-0,43$. оефіцієнт водостійкості в орному горизонті 0,54-0,76, у підорному - 0,42, в ілюві льному - 0,40 (див. т блицю).

грономічно цінною структурою $є$ дрібногрудкув т і зернист 3 грег т ми ді метром 0,25-10,0 мм, з якістю - шп рув т , мех нічно стійк і водостійк (ці вл стивості зумовлюють довготрив ле збереження структури в р зі обробітку грунту і після штучного бо природного зволоження) [1, с. 5].

ід ч с досліджень з'ясов но, що ясно-сірі т сірі лісові грунти смового обужжя м ють низький вміст грономічно цінних грег тів.

міст грономічно цінних грег тів у гумусово-елюві льному горизонті в ясносірому грунті під лісом ст новить у верхньому десятис нтиметровому ш рі - 30,43\%, у середній ч стині - 40,28, у нижній - 14,94 \% (див. т блицю). низ по профілю в елюві льному-сл бкогумусов ному горизонті - 20,13\%, в ілюві льно-сл бкоелювійов носл бкогумусов ному - 23,83 \%. ід ріллею ясно-сірого грунту в гумусово-елювільному горизонті у верхній ч стині вміст грономічно цінних грег тів ст новить $21,07 \%$, у середній - 29,69, в нижній - 19,75, в ілюві льно-елювійов но-сл бкогумусов ному - 13,72 і 15,24, в ілюві льно-сл бкоелювійов ному - 13,51\%. кі пок зники грономічно цінної структури є низькими, що зумовлено високим вмістом брилув тої фр кції (див т блицю).

езульт ти досліджень з свідчили, що вміст грономічно цінних фр кцій у грунт х під лісом вищий, ніж н ріллі, оскільки в процесі обробітку грунту руйнуються грономічно цінні грег ти.

сірих лісових грунт х ситу ція н логічн , як у ясно-сірих лісових. ід ріллею відсоток грономічно цінних грег тів у гумусово-елюві льному горизонті в ш р х 010, 10-20, 20-30 см ст новить, відповідно, 21,18, 12,17 і 16,65 \%. підорному горизонті їхній вміст збільшується до 25,17 \%, в ілюві льному-сл бкогумусов ному - до 29,98 \%.

ід лісом у гумусово-елюві льному горизонті в ш р х 0-10, 10-20, 20-30 см грономічно цінні грег ти, відповідно, ст новлять 25,63, 30,26 і 23,35\% униз по горизонту, в ілюві льному сл бкогумусов ному - 29,78 \%. тже, сірі лісові грунти м ють м йже одн ковий розподіл вмісту грономічно цінних грег тів по профілю, тоді як у ясно-сірих грунт х цей пок зник зменшується з глибиною.

тже, н ліз викон них досліджень д в змогу виявити певну з кономірність у профільній зміні структури сірих лісових грунтів. ід лісом, де грунти з зн ють зн чно меншого нтропогенного впливу, у верхньому гумусово-елюві льному горизонті перев ж є зернист структур, як $є$ н йсприятливішою і м є ліпші пок зники водостійкості, про що свідч ть д ні структурно- грег тного н лізу.

грунт х ріллі вн слідок інтенсивного сільськогоспод рського використ ння у верхньому орному горизонті перев ж є грудкув то-брилув т і дрібногрудкув то-бри- 
труктурно- грег тний ст н грунтів смового обужжя

\begin{tabular}{|c|c|c|c|c|c|c|c|c|c|c|c|c|c|c|c|}
\hline \multirow[b]{2}{*}{ 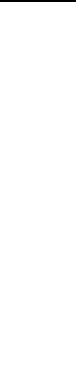 } & \multirow[b]{2}{*}{ 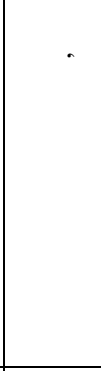 } & \multicolumn{9}{|c|}{ озміри грег тів, мм / вміст, \% } & \multirow[b]{2}{*}{ 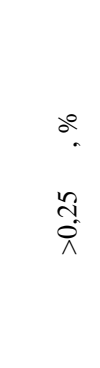 } & \multicolumn{3}{|c|}{$\begin{array}{l}\text { ок зники структурного } \\
\text { ст ну }\end{array}$} & \multirow[b]{2}{*}{ 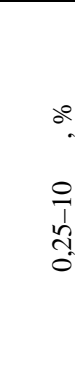 } \\
\hline & & $\stackrel{\circ}{\wedge}$ & $\stackrel{\jmath}{\jmath}$ & $\frac{n}{n}$ & in & ñ & $\stackrel{\beth}{\lambda}$ & \multirow[t]{2}{*}{$\begin{array}{l}n \\
0 \\
0 \\
0 \\
-= \\
9 \\
9\end{array}$} & \multirow[t]{2}{*}{ 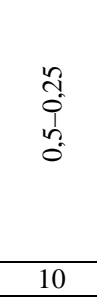 } & \multirow[t]{2}{*}{$\begin{array}{l}\text { ñ } \\
\text { हैं } \\
\\
11\end{array}$} & & \multirow[t]{2}{*}{ 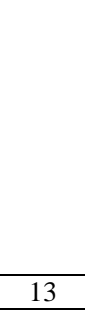 } & \multirow[t]{2}{*}{ 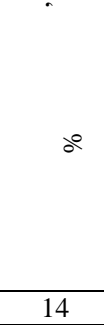 } & \multirow[t]{2}{*}{ 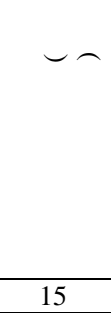 } & \\
\hline 1 & 2 & 3 & 4 & 5 & 6 & 7 & 8 & & & & 12 & & & & 16 \\
\hline \multicolumn{16}{|c|}{ озріз } \\
\hline \multirow[b]{2}{*}{$\mathrm{HE}$} & \multirow[b]{2}{*}{$2-29$} & \multirow[t]{2}{*}{62,45} & \multirow[t]{2}{*}{6,47} & 5,06 & 7,09 & 5,15 & 6,76 & 2,85 & 1,80 & 2,37 & \multirow[b]{2}{*}{71,5} & \multirow[t]{2}{*}{0,54} & \multirow[b]{2}{*}{203,24} & \multirow[b]{2}{*}{0,73} & \multirow[t]{2}{*}{35,11} \\
\hline & & & & 20,42 & 2,16 & 2,24 & 10,38 & 27,26 & 9,04 & 28,5 & & & & & \\
\hline \multirow[b]{2}{*}{$\mathrm{HE}$} & & 68,15 & 6,03 & 4,81 & 6,96 & 4,62 & 5,56 & 1,10 & 1,36 & 1,42 & & 0,44 & & & 30,43 \\
\hline & $2-10$ & & & 7,64 & 4,86 & 4,42 & 22,80 & 24,66 & 8,66 & 26,96 & 73,04 & & 240,03 & 0,74 & \\
\hline & & 57,28 & 8,27 & 6,29 & 7,94 & 5,52 & 7,97 & 2,41 & 1,89 & 2,43 & & 0,67 & & & 40,28 \\
\hline HE & $10-20$ & & & 17,02 & 3,14 & 3,04 & 13,70 & 20,26 & 10,52 & 32,32 & 67,68 & & 168,02 & 0,69 & \\
\hline & & 84,36 & 3,73 & 2,74 & 2,94 & 1,86 & 2,40 & 0,77 & 0,50 & 0,70 & & 0,18 & & & 14,94 \\
\hline HE & $20-29$ & & & 1,28 & 1,74 & 1,14 & 13,68 & 33,7 & 12,3 & 36,16 & 63,84 & & 427,31 & 0,64 & \\
\hline & & 79,06 & 5,09 & 3,77 & 4,16 & 2,73 & 2,95 & 0,90 & 0,55 & $\begin{array}{l}0,80 \\
\end{array}$ & & 0,25 & & & 20,13 \\
\hline Eh & $32-42$ & & & 1,32 & 0,44 & 1,02 & 11 & 30,52 & 12,34 & 43,36 & 56,64 & & 281,23 & 0,57 & \\
\hline & & 79,34 & 3,05 & 3,57 & 4,61 & 3,09 & 3,81 & 1,08 & 0,66 & $\begin{array}{l}0,78 \\
\end{array}$ & & 0,25 & & & 19,88 \\
\hline Eh & $30-40$ & & & 3,68 & 1,14 & 1,7 & 11,34 & 27,98 & 15,24 & 38,92 & 61,08 & & 307,24 & 0,62 & \\
\hline & & 79,32 & 4,92 & 3,62 & 4,70 & 2,61 & 2,81 & 0,81 & 0,49 & 0,74 & & & & & 19,55 \\
\hline Eh & $40-45$ & & & 3,48 & 0,82 & 0,7 & 3,34 & 31,5 & 16,56 & 43,60 & 56,4 & 0,25 & 282,71 & 0,57 & \\
\hline & & 76,16 & 5,57 & 4,32 & 5,16 & 3,19 & 3,60 & 1,04 & $\begin{array}{l}0,59 \\
\end{array}$ & 0,36 & & & & & 23,83 \\
\hline & & & & 2,84 & 0,38 & 0,64 & 2,44 & $\begin{array}{l}31,58 \\
\end{array}$ & 14,06 & 48,06 & & & 221,3 & 0,52 & \\
\hline & & & & 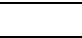 & $\mathrm{cr}$ & оий лі & легко & ИИНКОВИ & лесопо & Iих сугл & $\mathrm{x}$ (рілл & & & & \\
\hline & & 76,8 & 5,23 & 3,54 & 4,17 & 2,72 & 3,03 & 1,48 & $\begin{array}{l}0,90 \\
\end{array}$ & 2,12 & 45,28 & 0,27 & & & 21,07 \\
\hline Heop & $0-10$ & & & 1,12 & 0,88 & 0,56 & 2,8 & 21,08 & 18,84 & $\begin{array}{l}54,72 \\
\end{array}$ & & & 225,61 & 0,46 & \\
\hline & & 68,35 & 8,27 & 5,66 & 6,40 & 3,47 & 3,91 & 1,13 & 0,84 & 1,96 & & 0,42 & & & 29,69 \\
\hline HEop & $10-20$ & & & 1,28 & 1,18 & 0,38 & 2,58 & 20,18 & 21,44 & 52,96 & 47,04 & & 158,44 & 0,48 & \\
\hline
\end{tabular}


кінчення $m$ бл.

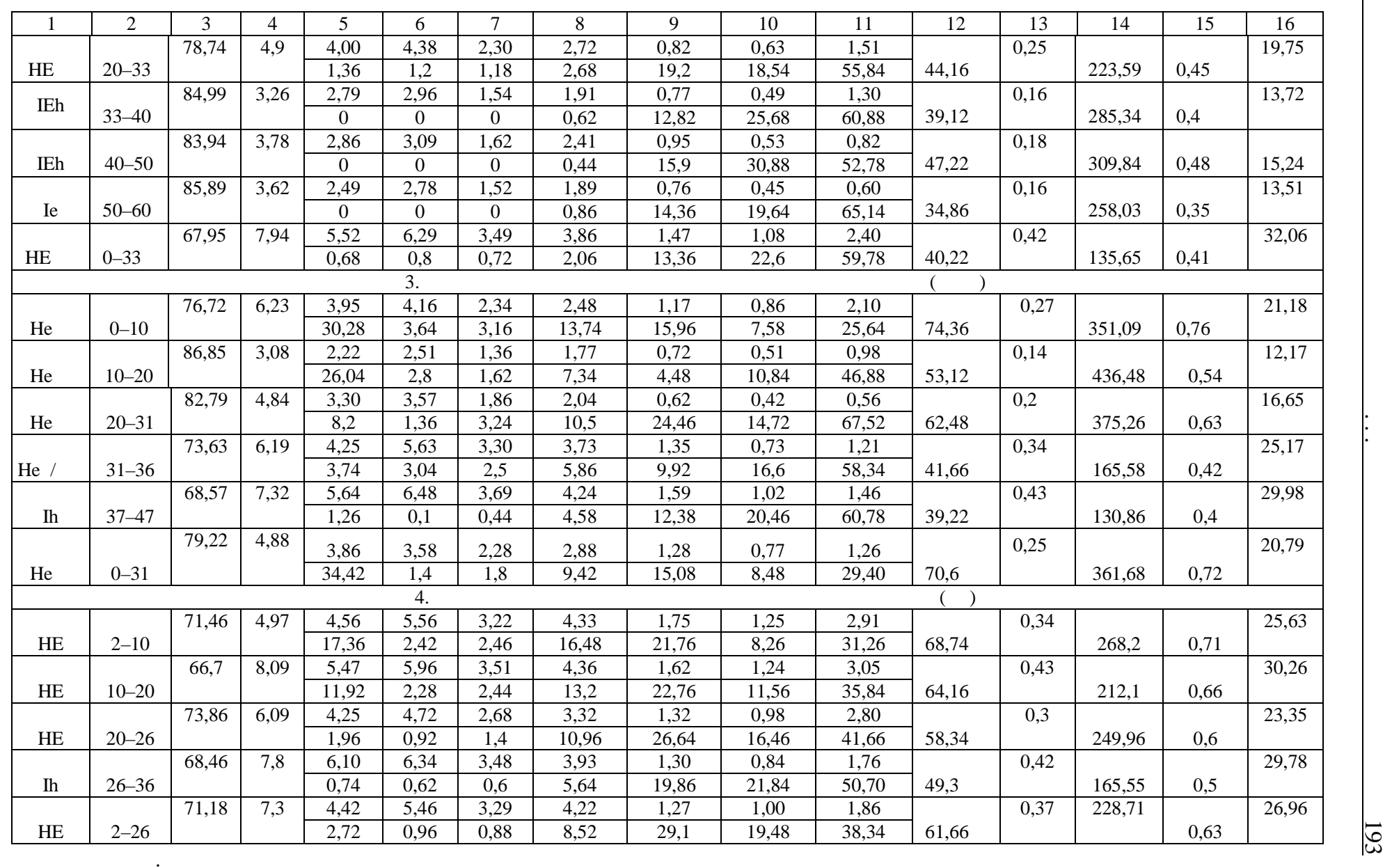

р и м і т к : чисельник - сухе просіюв ння, зн менник - мокре. 
лув т структури. творення груд і брил $є$ н слідком дії н грунти в жкої сільськогоспод рської техніки, ун слідок чого руйнується сприятлив зернист структур , н iï місці утворюються груди і брили. люві льний горизонт сірих лісових грунтів м $є$ грудкув то-горіхув ту і горіхув то-призм тичну структуру.

ясно-сірих і сірих лісових грунт х під лісом змін структури по профілю є яскр во вир женою і х р ктерною для цього типу грунтів. ростежено 3 кономірну зміну структури від зернистої у верхніх ш р х до горіхув тої і горіхув то-призм тичної в ілюві льному горизонті. грунт х під ріллею вн слідок нтропогенного н в нт ження відбув ється змін структури по профілю від грудкув то-брилув тої в орних горизонт х до грудкув то-горіхув тої в ілюві льному.

1. чинский . . труктур почвы (итоги и перспективы изучения вопрос ) / . . чинский. . : зд-во оск. ун-т , 1963. - $100 \mathrm{c.}$

2. чинский . . изик почвы. . 1./ . . чинский. - . : ысш я шк., 1965. -323 с.

3. едведев . . труктур почвы (методы, генезис, кл ссифик ция, эволюция, геогр фия, мониторинг, охр н )/ . . едведев. - рьков : 13 типогр фия, 2008. - 406 с.

4. оз нов . . орфология почв / . . оз нов. - . : зд-во оск. ун-т, 1983. -320 с.

5. $\quad$. . . троение и устойчивость почвенных грег тов / . . н, . . оздняков, . . он // очвоведение. - 2007. - № 4. - . 450-456.

m ття: н дійшл до редколегії 21.10.2011

прийнят до друку 20.12.2011

\section{PROFILE ORGANISATION STRUCTURE OF GRAY FOREST SOILS OF RIDGED POBUZHIA}

\section{Denys}

Ivan Franko National University of Lviv, . Doroshenko St., 41, UA - 79000 Lviv, Ukraine

The results of field and laboratory studies of structural and aggregate state of gray forest soils of the region are discussed. The paper ccharacterizes the organization structure of the soil profile and its changes under different biocenoses. The influence of anthropogenic factors on the parameters of the structural state of soils is shown.

Key words: gray forest soils, light gray forest soils, structure, morphology, aggregate, structuring factor, the coefficient of water resistance.

- енис

ьвовский н ицон льный университет имени в н рнко,

ул. . орошенко, 41, г. ьвов, 79000, кр ин

риведено результ ты полевых и л бор торных исследов ний структурно- грег тного состояния серых лесных почв рядового обужья. х р ктеризов но орг низ цию структуры почвы по профилю и ее изменение под р зными биоценоз ми. ро н лизиров но влияние нтропогенного ф ктор н пок з тели структурного состояния почв.

лючевые слов : серые лесные почвы, светло-серые лесные почвы, структур , морфология, грег т, коэффициент структурности, коэффициент водостойкости. 